\title{
The role of offset and technology transfer for installing an aeronautical industrial pole
}

\author{
O papel do offset e da transferência de tecnologia para Instalação \\ de um polo aeronáutico
}

\author{
Felipe Fernandez ${ }^{1,2}$ (D), Rogério Santos da $\operatorname{Costa}^{1,3}$ (D), Bianca Tonelli ${ }^{1,4}$ (D), \\ Nathany Fernanda Tavares Vieira ${ }^{1,5}$ (D) \\ ${ }^{1}$ Grupo interdisciplinar de pesquisa em dinâmicas globais e regionais - GIPART, Programa de Pós-graduação em \\ Ciências Ambientais, Universidade do Sul de Santa Catarina - UNISUL, Palhoça, SC, Brasil. \\ ${ }^{2}$ Universidade do Sul de Santa Catarina - UNISUL, Programa de Pós-graduação em Administração, Florianópolis, \\ SC, Brasil. E-mail: felipefernandez65@hotmail.com \\ ${ }^{3}$ Universidade do Sul de Santa Catarina - UNISUL, Programa de Pós-graduação em Ciências Ambientais, Grupo \\ Interdisciplinar de Pesquisa em Dinâmicas Globais e Regionais - GIPART, Florianópolis, SC, Brasil. E-mail: \\ paralelosc46@gmail.com \\ ${ }^{4}$ Grupo Interdisciplinar de Pesquisa em Dinâmicas Globais e Regionais - GIPART, Florianópolis, SC, Brasil. E-mail: \\ biancatl@hotmail.com \\ ${ }^{5}$ Universidade de Granada/ES, Departamento de Ciência Política, Granada, Espanha, E-mail: \\ nathanytavaress@gmail.com; nathy_ftv@hotmail.com
}

How to cite: Fernandez, F., Costa, R. S., Tonelli, B., \& Vieira, N. F. T. (2021). The role of offset and technology transfer for installing an aeronautical industrial pole. Gestão \& Produção, 28(1), e4874. https://doi.org/10.1590/1806-9649.2020v28e4874

\begin{abstract}
This is a unique case study of a phenomenological, exploratory and qualitative approach, with a horizontal temporal cut. The goal of the present study was to bring up the current stage of a small aeronautical industry in Santa Catarina in regards to offset and technology transfer tools. In order to achieve this goal, data collection involved interviews, assembly line observation and web page analysis. The results indicate a positive outlook regarding the offset, despite its non-use. The perception about technology transfer is negative, being verified that the organization needs external technologies.
\end{abstract}

Keywords: Technology gap theory; Technology diffusion; Military offset; Technology transfer; Aeronautical industrial Pole in Santa Catarina/Brazil.

Resumo: Este é um estudo de caso único de abordagem fenomenológica, exploratória e qualitativa, com recorte temporal horizontal. O objetivo do estudo foi fazer emergir o estágio atual de uma pequena indústria aeronáutica catarinense em relação às ferramentas de offset e transferência de tecnologia. Para atingir este objetivo a coleta de dados envolveu entrevistas, observação da linha de montagem e análise de páginas da internet. Os resultados indicam visão positiva em relação ao offset, apesar do seu não emprego. A percepção sobre a transferência de tecnologia é negativa, constatando-se que a organização necessita de tecnologias externas no seu dia-a-dia.

Palavras-Chave: Teoria do gap tecnológico; Difusão tecnológica; Offset; Transferência de tecnologia; Polo aeronáutico em Santa Catarina/Brasil.

Recebido em Dez. 31, 2018 - Aceito em Sept. 22, 2019

Financial support: None.

This is an Open Access article distributed under the terms of the Creative Commons Attribution License, which permits unrestricted use, distribution, and reproduction in any medium, provided the original work is properly cited. 


\section{Introduction}

The end of the Cold War period characterized by bipolarity and nuclear tension between the United States of America and the former Union of Soviet Socialist Republics (USSR) presented a scenario of greater stability and apparent absence of major threats in the International System. (Carneiro, 2008)

This situation required the reduction of military spending even among the greatest powers. Facing this scenario, as well as the arise of globalization and the growing interconnection between the industrial chains worldwide, the nations that traditionally imported their military equipment responded by demanding industrial compensation (offset) and technology transfer (T\&T) from the exporting countries.

Petersen (2011) analyzed the impacts of the offset tool on industrial bases and security matters in the North-American context, and pointed out as results concerns regarding market predominance in the development of offsets policies. According to this author, market policies and national policies are not always aligned. Welt (1986) worried about the development of matter as a potential competitive tool.

Palia, in several case studies (Palia, 1992; 1993; Palia \& Liesch, 1991; 1997; Palia \& Yoon, 1994; Liesch \& Palia, 1999), on the other hand, stood out in this field of study, being responsible for studies of the commercial compensations in various national contexts, as in the cases of Australia $(1991,1997,1999)^{1}$, Indonesia (1992), Japan (1993) and both North and South Korea (1994), among others. This studies looked into identifying and typifying countertrade (commercial counterparts) ${ }^{2}$. He identified in the national contexts the most commonly used types of countertrade, and classified them into compensations, offsets and counter-purchases. In this context, countertrade is still used as a marketing tool.

In Brazil, Fiegenbaum \& Rondinel (2006) published (in Spanish) a case study called "Offset Agreements of Commercial, Industrial and Technological Compensation: A Case Study of Brazil". This work presented a historical review of the use of the tool in Brazil and its results pointed out that its introduction and development were mainly held by the Ministry of Aeronautics. For these authors, this body was responsible for incorporating the theme to Brazil's commercial, industrial and technological policy. In fact, there were benefits such as shortening the path of access to new technologies, anticipating the product lifecycle, and direct compensation agreements.

Subsequently, this issue was raised at strategic level in Brazil, with the National Defense Strategy (Brasil, 2008, p.9) stating that "Who does not have the domain of sensitive technologies, either for defense or for development is not independent."

Considering this context, the present study aims to answer the following research problem: what is the current stage of a small aeronautical industry in Santa Catarina in regards to offset and technology transfer tools? So, the research seeks to identify the understanding and perception of the managers of the company Wega Aircraft, located in the city of Palhoça, Santa Catarina / Brazil, in regards to the offset and the technology transfer and evidence of the use of offset and technology transfer tools by the company.

This study allows a partial and limited empirical contribution to the case studied. However the research can contribute with the description of the company studied and follow the changes in its development related to the topic of offsets and technology transfer over 3 years.

\footnotetext{
${ }^{1}$ With LIESCH, Peter W; In Australian cases and with YOON, Heon Deok; In the case of the Koreas.

2 Unlike Brazil, where the terms are commonly used as synonyms, in the international arena offset and countertrade are considered to have different meanings, although complementary ones. In this context, offset would be a type of countertrade.
} 
With regards to the master plan of the city of Palhoça and its surroundings, there is the possibility of encouraging the use of offset as an auxiliary tool for technology diffusion, creating jobs and income at industrial poles with potential for centrifugal induction.

With regards to the city of Palhoça and its surroundings, the research also allows us to verify, through the previous experiences demonstrated in the theoretical reference, the potential benefits that can be extracted from the use of offset as a tool capable to assist in the development of the local aeronautical company.

\section{Theoretical Framework}

This study seeks to broaden the understanding of offset and technology transfer tools. These tools can be considered part of the phenomenon of technology diffusion. The phenomenon of technology diffusion is seen, according to the technology gap approach, as being central to understanding the issues of development and underdevelopment.

The school of technology gap approach presents economic growth as a function of the technology gap and the capacities of research, development and use of opportunities of the countries. (Fagerberg, 1987; Lindbeck, 1983; Parvin, 1975; Cornwall, 1976, 1977). Among the singularities of the theory of the technology gap is the dichotomy between Innovation as willingness to increase the degree of economic and technological differentiation between the countries, and, on the other hand, Diffusion as a way to resolve these differences (Jones, 2000).

Some countries have been more successful compared to others and this could be explained by the sense of opportunity in their geopolitical situation and maturation in the reformulation of strategies (Cândido, 2010). The copying and absorption of foreign technology start being analyzed through the speed of economic growth and the search for convergence with global technological frontiers. (Godinho, 1995)

Based on the understanding of the technology gap approach and the need to suppress this gap as a way to reach development, countries and organizations are beginning to pay attention to the phenomenon of technology diffusion and to seek tools that can serve for this purpose. In the case of this research the focus is on two of these tools, offset and technology transfer.

A very close definition of the idea that people generally have of technology is presented by Rocha (1996), who considers it as the "knowledge applied to the production of goods and services and their processes". Another definition is provided by Viotti et. al. (1997, p.26), which admits that technology "comprises a set of scientific knowledge useful and applicable to a wide range of projects, processes and products".

Thus, the concept of technology transfer observed here is that of Peters (2000), who states that technology transfer is the process by which an existing technology is applied to a new use or user. For this author, the process relies almost exclusively on the existing technological base, promoting the increase of the intensity of its use, rather than the expansion of the base through a research and development (R \& D) effort.

In Brazil, INPI (National Institute of Industrial Property) points out that "technology transfer is the process through which a set of knowledge, skills and procedures applicable to the problems of production are transferred, through an economic transaction, from one organization to another, increasing the capacity of innovation of the receiving organization ". (INPI, 2005; s / p.). 
Thus, according to Rogers (2010), technology diffusion represents a process that starts with a new idea, then, person "A" who knows about innovation, and person "B" who does not yet know about innovation, maintain a social relationship "A" and "B" consisting of a large agreement on the conditions under which " $A$ " will speak to " $B$ " about innovation and its results. For Kupfer (1996) the process of technology diffusion through the point of view of traditional theories would consist of a process of adjustments that would take place at the moment when an innovation disturbs a previously balanced system.

For Nelson \& Winter (1982), innovation constitutes an endogenous process, from the inside to the outside, with organizations ignoring the selection process by the market. For Dosi (1984), the triad composed of science, technology and production would form a space where multiple interactions would take place, and it would be impossible to determine the dominance nature of these relations. In this sense, the selection of these would occur later on the market, making the innovation processes in this space impossible to be predicted.

It is possible to state that one of the main motivations for the offset practices is that, although the new technologies are a necessary input to the process of development and to the increase of productivity, and serve as mechanisms for generating "competitive advantages", these extrapolations on knowledge barriers represent a high cost for most countries. (Fernandez et al., 2012; Ivo, 2004)

According to Ivo (2004), the acquisition of technology under the terms of the offsets agreements serves as means of reducing costs with the internalization of knowledge, thus reducing the steps for reaching the state of the art in a specific sector. In general, the instrument generates an improvement in competitiveness.

The offset is interpreted in three main ways: as an excessive burden for weapon exporting countries (OMB, 1988); as a strategic partnership, for importing countries such as Brazil (Brasil, 2008); and as a marketing tool for export companies of defense products (Dumas, 2004).

The Defense Industry Department of the Federation of Industries of the State of São Paulo (COMDEFESA / FIESP), in 2015, prepared a study aiming to broadening the understanding of offsetting in the sector. According to COMDEFESA (2015), the offset started in the 1940s in the field of civil negotiations, with agricultural exchanges for strategic minerals. Also for COMDEFESA (2015, p. 13), in the 1960s the use of these mechanisms was intensified "mainly motivated by importers who wanted to expand and qualify their BID and by exporters that aimed to create dependence of these buyers on them, making them dependent, commercially and politically."

For the purposes of this study, offset is conceptually understood just as the Brazilian Ministry of Defense (MD) (Brasil, 2002) defines it, as "any compensatory practice agreed upon by the parties as a condition for importing goods, services and technology, with the intention of generating benefits of industrial, technological and commercial nature ".

\section{The Offsets Usage history in Brazil}

In Brazil, the offset agreements had the pioneering role of the Brazilian Air Force and date back to the 1950s when the Gloster Meteor fighter was purchased in England and the countertrade was used to purchase the aircraft, and was compensated by an equivalent value in Brazilian cotton (Flores, 1998). 
When it became necessary to replace these aircraft with a more modern type, in the 1970s, Brazil acquired Northrop Grumman F-5 E / F Tiger II aircraft, and the offset was agreed upon as co-production of aircraft fuselages, resulting in the acquisition of habilities in the area of metal-metal welding, compound materials and numerical control machine use, according to Bernardes (2000). The qualification received from these agreements was important in the consolidation of EMBRAER as an aerospace industry, using the ability received in subsequent projects of the company.

As noted by Modesti (2004) in 1979, there was an agreement in which Boeing 737 and Airbus A-300 aircraft acquired by Brazilian airlines, Varig (Rio Grande Airway) and Vasp (São Paulo Airway), had their seats manufactured by EMBRAER. Also in the field of aircraft contracted by Brazilian airlines, in the 1990s, the acquisition of MD-11 aircraft by VARIG was compensated by the hiring of EMBRAER as a supplier of the Flap sets of these aircraft.

According to the author, in the 1980s the agreement with the Canadian company Spahr for the acquisition and launching of the Brasilsat satellites 1 and 2 involved offsets worth US \$175 million, for example the installation of the Telebrás technology center in Brasilia.

Regarding the naval sector, Vargas (2004) states that in the experience of the Navy with Offsets, compensation agreements were concentrated in the Rio de Janeiro Navy Arsenal (AMRJ), following a policy that forced foreign shipyards to build part of the ships in Brazil. Sam Perlo-Freeman (2004) states that these agreements sought to reach the highest percentage of national content possible.

Sam Perlo-Freeman (2004) points out that one of the offsets agreements signed by Brazil occurred in the production under license of the Armacchi-326 aircraft, known in Brazil by EMB-326 Xavante. The technologies acquired in this process were used in the later development with the same Italian company and also Alenia, another Italian aeronautical company of the AMX-A1.

According to the author, the A-1 aircraft, even though it was a failure in market terms, enabled the acquisition of technologies used in ERJ family jets that transformed EMBRAER into one of the largest aeronautical companies in the world, reaching $40 \%$ of Market share in 1999.

According to Modesti (2004) another major offset operation was the purchase of the Integrated Center for Defense and Aerospace Control - CINDACTA I, from the French company Thompson and resulting in the sale to the French Air Force of 41 Embraer Xingu aircraft, used in the training of French pilots of transport aircraft. Also in the 1980s, when the decision to reactivate Brazilian army aviation exclusively with helicopters was made, the option of the French company Eurocopter caused 50 Embraer T-27 tucano training aircraft to be acquired by the French Air Force.

Sam Perlo-Freeman (2004) points out that in 1992 there was an agreement in which Piper undertook to transfer technology for the construction of light aircraft Seneca to EMBRAER.

In 1997, the acquisition of SIVAM/SIMPAM resulted in 2.8 billion dollars in offsets contracts, costing approximately US $\$ 1.4$ billion. Among the results of these agreements, ATECH Tecnologias Criticas, a Brazilian company specialized in software development and systems integration, became the only company in Latin America to manufacture software for air defense and control.

In 1991 and 1992, the Commercial, Industrial and Technological Compensation Policy of the former MAER and Directive 360-1, which regulated the Brazilian Policy of the time, according to Modesti (2004) were approved. 
Fiegenbaum \& Rondinel (2006) state that on November 3, 1997, Order No. 749 / GM4 entered into force, which stated that the Ministry of Aeronautics, in its edicts and consequently in its contracts, must necessarily have agreements of compensation in exchange for large military purchases, establishing qualifications for the approval and conclusion of contracts. Also according to those authors at the end of 2000, the Navy Command of Brazil approved its compensation policy, contemplating the requirement of compensations in the imports of equipment and systems for the benefit of the Brazilian Navy and the naval industry.

On December 27, 2002, by means of Normative Instruction No. 764 / MD, the Commercial, Industrial and Technological Compensation Policy of the Ministry of Defense was approved, which undertook the strategic coordination of offsets policy for the defense industry, in the imports of systems and equipment by the Brazilian Armed Forces. (Fernandez, 2015).

\section{Methodology}

This study may be classified as exploratory, mixed, in the form of a single case study, and using a horizontal approach. The mixed- exploratory nature of the study is justified by addressing a revealing phenomenon (technology diffusion) and by investigating a complex reality. The single case study method was employed because the study seeks to understand in depth the investigated phenomenon, in a context that involves numerous variables and high instability of occurrence, which requires an intensive study (Yin, 2009).

The object of study included the company Wega Aircraft located in the city of Palhoça in the State of Santa Catarina / Brazil that operates in the sector of small aircraft of single-engine aircrafts and hydrofoils, classified as small, according to BNDES classification criteria (BNDES, 2012). The choice for this company is due to the fact that it is one of the two companies representing the beginning of an aeronautical pole in Santa Catarina.

This study presents more research variables than sample elements and, therefore, requires triangulation in data collection, as recommended by Creswell (2007). Thus, different sources were applied in the collection of data, including observation, personal interview, analysis of web pages and bibliographical and documentary research. Data collection was performed following the recommendations of Bell (2008) and Flick (2009) and the sample for the interview was selected as convenient.

The direct observation and the initial interviews occurred on 03/09/2016 at the premises of the company Wega Aircraft. After the observation of the assembly line and the unstructured interview with 2 employees of the company's aircraft assembly line and 2 employees of the hydrobus assembly line, the owner and founder of the company Mr. Jocelito Wildner and an intervening leader were interviewed (Director of the Committee for the Development of the Aeronautical Industry of the Federation of Industries of the State of Santa Catarina - FIESC), Mr. César Olsen, having used in these interviews a preliminary semi-structured script.

On 07/11/2018 a new interview was held with the owner of the company Wega, Mr. Jocelito Wildner, to follow the development of the company over the last few years, with a duration of 45 minutes and a structured script.

The Table 1 below presents the interviewees, the format of the interviews and the year in which they were carried out, the format used with each one and its duration, as well as the profile of the interviewees. 
Table 1. Description of the interviewees and their profile, format and interview duration.

\begin{tabular}{|c|c|c|c|c|}
\hline $\begin{array}{l}\text { Entrevistas } \\
\text { Realizadas }\end{array}$ & Format & Duration & Interviewee Profile & $\begin{array}{c}\text { Year of Interview } \\
\text { (s) }\end{array}$ \\
\hline \multirow{2}{*}{$\begin{array}{l}\text { Jocelito } \\
\text { Wildner }\end{array}$} & \multirow{2}{*}{$\begin{array}{l}\text { Semi- } \\
\text { Structured } \\
\text { Roadmap }\end{array}$} & $\begin{array}{c}62 \text { minutes } \\
(2016)\end{array}$ & \multirow{2}{*}{ Owner and Founder } & \multirow{2}{*}{2016 e 2018} \\
\hline & & $\begin{array}{l}48 \text { minutes } \\
(2018)\end{array}$ & & \\
\hline César Olsen & $\begin{array}{l}\text { Semi- } \\
\text { Structured } \\
\text { Roadmap }\end{array}$ & 35 minutes & $\begin{array}{l}\text { Director of the } \\
\text { committee for the } \\
\text { development of the } \\
\text { aeronautical industry } \\
\text { of FIESC }\end{array}$ & 2016 \\
\hline worker 1 & $\begin{array}{c}\text { Not } \\
\text { Structured }\end{array}$ & 7 minutes & $\begin{array}{c}\text { Operator of the } \\
\text { Aircraft Assembly } \\
\text { Line of the Company }\end{array}$ & 2016 \\
\hline worker 2 & $\begin{array}{c}\text { Not } \\
\text { Structured }\end{array}$ & 5 minutes & $\begin{array}{c}\text { Operator of the } \\
\text { Aircraft Assembly } \\
\text { Line of the Company }\end{array}$ & 2016 \\
\hline worker 3 & $\begin{array}{c}\text { Not } \\
\text { Structured }\end{array}$ & 3 minutes & $\begin{array}{l}\text { Operator of the } \\
\text { Airboats Assembly } \\
\text { Line of the Company }\end{array}$ & 2016 \\
\hline worker 4 & $\begin{array}{c}\text { Not } \\
\text { Structured }\end{array}$ & 8 minutes & $\begin{array}{l}\text { Operator of the } \\
\text { Airboats Assembly } \\
\text { Line of the Company }\end{array}$ & 2016 \\
\hline
\end{tabular}

By authors (2018).

The presence of the intervening director in the research is justified by his power in the company, since it is an unconsolidated pole, whose consolidation concerns the Federation of Industries and the State. The decision regarding his participation in the survey was also due to the absence of a high-level sample, since the sole manager of the company was also its owner, who accumulated technical and management functions. This decision was supported by the collection of electronic documents, which pointed to the relevance that the intervening director had in the company. He was also the only one to go along the owner to the main business fair of the sector $(G 1,2013)$.

Access to web pages was held on 09/10/2016, between 00:22 a.m. and 6:52 a.m. A new electronic data collection was conducted on 10/22/2018 between 19:00 and 22:00 specifically on the official website of the company Wega Aircraft. The criterion used for analysis of websites included all webpages that returned from Google's search engine when the company name was typed in quotes.

After transcripts of the interviews, the need arose to be sure about the veracity of the statements of the interviewees about the certification of companies in the aeronautical sector. The researchers decided, then, to include in the triangulation of data a visit to the Brazilian National Civil Aviation Agency (ANAC, 2019) page, even though it did not meet the inclusion and exclusion standards previously planned. This procedure was done in the same period as the access to the other webpages. This decision was motivated by the exploratory nature of the research, which enabled this adaptation.

The collected data were analyzed in light of the mixed-approach content analysis method, including word counting and thematic affinity data categorization as recommended by Flick (2009), Franco (2008) and Bardin (2009). The categorization 
involved the fragmentation, classification and grouping of collected data previously defined based on the specific objectives and the interview script.

\section{Company Description, Product Mix and Employee Development (2013- 2018)}

Wega Aircraft was founded in March 2006 by Mr. Jocelito Carlos Wildner, aircraft mechanic, formed by the VARIG school, and had as its initial goal according to the company's website "to manufacture lightweight composite aircraft kits of high quality, using state-of-the-art techniques and components, thus filling the gap in the Brazilian market. "

The company located in the city of Palhoça, State of Santa Catarina / Brazil, operates in the sector of small single motor aircraft and hydrofoils, and is currently classified as a small business, according to BNDES classification criteria (2012).

The company increased its product mix with the creation of the Eolo Aerobarco and the Wind Machine. In the segment of light wing single motor aircraft the company offers the planes Wega FG, Wega 180 and Wega XP 400, all these aircraft with twopassenger cabins seated side-by-side seagull type. The main variation between the products is in the powertrain, with the Wega FG engine options from 100 up to $160 \mathrm{hp}$, the Wega 180 from $180 \mathrm{hp}$ and the Wega XP 400 so far has $215 \mathrm{hp}$ engine. The company's aircraft, according to the interview with its owner, were provided to private customers in Brazil and Argentina for sports and recreational use.

In the case of the hydrofoil this is described on the company website as being built in FIBERGLAS and the company points out that the differential of the boat compared to other conventional boats is the condition of being able to operate in shallow water and with a lot of aquatic vegetation or mud. The main customers of the hydrofoil were the Military and Environmental Police in states of the Pantanal region, as well as individuals in those same states who bought it for recreation purposes. The market for Aerobarco, according to the CEo of the company Wega, was restrictive mainly due to the price of the product, which is around 100 thousand reais (about US $\$ 20,000$ )..

The website of the company (WEGA, 2016) does not offer more descriptions of the wind machine, however the owner of Wega described it in the interview as being a "giant fan" used to simulate wind, having as only customer so far Rede Globo de Televisão. The wind machine uses the same motor of the hydrofoil and adds used canisters to direct the wind.

The research may prove that the company lived its peak between the years of 2013 and 2015 , having increased considerably its staff during that period and recently declined with the impact of the economic crisis that started to hit Brazil from that time on, remaining only the owner as responsible for all the activities of the company in 2018.

Also according to the interview with the owner of the company in 2018 , in the year 2013 the company's staff only had technical staff, in 2015 there was a professional who only had the elementary education, 2 professionals with a higher level including a mathematician and 8 technicians, and in 2018 there was only him as an employee, having said that he has the technical level. However, it can be observed that despite the reduction of employees, the premises of the firm remained the same size until the date of last observation on 11/11/2018.

Table 2 below shows the evolution of the number of employees and their level of qualification in the period from 2013 to 2018. 
Table 2. number of employees and their level of qualification (2013 to 2018).

\begin{tabular}{|c|c|c|c|}
\hline Year & 2013 & 2015 & 2018 \\
\hline No. of Employees & 7 & 11 & 1 \\
\hline \multirow{3}{*}{$\begin{array}{c}\text { Employee } \\
\text { Qualification Level }\end{array}$} & \multirow{3}{*}{$\begin{array}{c}\text { Technical degree } \\
\text { (7) }\end{array}$} & middle school (1) & \multirow{3}{*}{$\begin{array}{c}\text { Technical degree } \\
\text { (1) }\end{array}$} \\
\hline & & Technical degree (8) & \\
\hline & & Bachelor degree (2) & \\
\hline
\end{tabular}

By authors (2018).

\section{Technological Aspects: National Content, Project Efforts and Absorption Capacity}

Cohen \& Levinthal (1999) understand absorption capacity as the ability to recognize the value of new knowledge, to assimilate it, and to apply it for commercial purposes. These authors argue that this capability is critical to the company's innovative performance. For them, such capacity is cumulative and depends on a number of characteristics of the companies, correlated with the individual skills of their employees and their internal organization, as well as their previous investments in Research and Development (R \& D).

According to the information above, we present an overview of the company's current research and development efforts, use of technology, supply structure, national content, current technological capabilities, internal learning mechanisms and absorptive capacity.

With regard to research and development efforts, given the serious economic crisis of recent years, the only project underway at Wega Aircraft is the project for the construction of a 4-seater aircraft, informally called by the owner of Wega $4 \mathrm{p}$. Such a project has stopped on the drawing boards due to lack of resources to finalize a prototype, and it is the only project that the company presented in the interview with the owner in 2018. In addition, the company needs to concentrate the existing resources in the completion of an aircraft under production, which is currently the only order in the company's portfolio.

With regard to the company's supply structure and its relation to the national content, according to the company owner some technologies that were initially supplied by foreign customers were later purchased from domestic suppliers. In the first aircraft for example the sets of wheels and brakes were bought from suppliers of the United States and are currently purchased in Brazil. In addition, from the beginning the aircraft received lining material, resins, acrylic and steel of national origin.

The most recent effort to increase national content in the company was in the attempt to use the national glass fiber and carbon fiber in the construction of aircrafts. However, according to the owner, the company must restart importing this material for the construction of future aircraft, since according to him, the national fabric is not suitable for epoxy, despite a statement to the contrary by the suppliers. Therefore, the company believes that it will be necessary to improve quality in this national material in the future so that they can effectively replace imported content by national content. $\mathrm{He}$ also comments on the possibilities of using the national carbon, noting that at that time the existing types of weave still lack in quality.

According to the owner of the company, he would like to have more mechanical components of the aircraft produced by the national industry, since he thinks that 
because Brazil has one of the largest civil aviation fleets in the world, it would have enough demand for so. The purchase of these items in Brazil could facilitate logistical issues.

About the supply structure, the main foreign components currently purchased are the Lycoming piston engines, and the cockpit instruments in the United States of America, while the propellers are supplied by a German supplier. The owner also believes that currently about $50 \%$ of the aircraft uses domestic content with the other half being imported.

On the internal mechanisms of learning the owner pointed out that in the beginning of the company the purchase of books and technical materials, including from abroad was one of the main learning mechanisms employed. At that time the company also tried to employ technology transfer, with the purchase of plans of an aircraft designed by a professor from Minas Gerais/Brazil. However the negotiation stumbled on commercial issues and technical quality, having the company completely redesigned the aircraft.

Currently, according to the owner of the company, the internet has consolidated as the main learning mechanism in the company. The trial-and-error method still plays an important role. The company reported, for example, a loss of 250,000 reais (about US $\$$ 50,000 ) in acrylic until it was able to obtain the necessary parts and parts and expertise in the handling of the product, today one of its main competitive advantages.

Regarding the technological and scientific capacities of the company, the owner reinforced in the interview in 2018 what had already been stated in 2016 on the company's capabilities in the handling of materials in fiberglass and carbon fiber. The company has technological capabilities in the handling of these materials and in their transformation.

In addition, Wega is able to integrate equipment of different origins in its production and its subsequent maintenance. Therefore, the aviation composite construction applied to aviation is the main technological capability of Wega Aircraft, according to the owner of the company. Public domain technologies also play a major role in the company, such as vacuum melt lamination, which results in quality composites.

It is possible to affirm that the company presented at a given moment absorption capacities consistent with the analytical framework presented by De Negri (2006, page 28). This is because the experience of the professionals, the training of these professionals, the use of almost continuous resources in $R \& D$ efforts and the verification of innovations made by the company in some specific areas, such as the use of composite materials applied to aviation, is an indicator of absorptive capacity, according to said instrument.

On the other hand, the crisis faced by the company, with the dramatic reduction in the number of employees and investments in $R \& D$ makes it uncertain to determine the extent to which these capabilities are maintained, even though in the interviews with the company manager, the company has stated that it is capable to absorb knowledge from potential offset agreements.

\section{Data Analysis and Presentation of Results}

In this section we analyze the data and present the results of the field research. In addition, we discuss what was captured from the managers' discourse regarding their perception of offset and technology transfer. In cases where differences between what 
was established by theory and managers' positions were noticed, these differences were conflicted with the results of observation and analysis of web pages.

Among the main aspects of the offset that were raised by managers, stakeholders and employees interviewed, it is possible to highlight their understanding on the subject, their concerns about the legal frameworks of commercial offset in Brazil, and the applicability for receiving benefits. Other aspects that emerged from the interview were the fear regarding the possibility of corruption in the process of receiving offsets and the questions about how to turn the offset into business.

As for the interviewees' understanding of the offset tool, the interviews in 2016 clarified they presented knowledge regarding the subject. Content analysis showed that the term offset, with 36 occurrences throughout the transcripts, was the main subject addressed throughout the interviews, surpassing the term technology, another focus of the study that presented a number of 26 occurrences.

As shown in table number two, none of the respondents presented a theoretical or documentary definition on offset, while they demonstrated that they had knowledge of the existing legislation in Brazil on the subject. The Table 3 below contrasts the offset definitions according to the Brazilian MD and the US Office of Management and Budget to those presented by the owner of the company Wega Aircraft and the director of the committee for the development of the aeronautical industry of the Federation of Industries of the State of Santa Catarina (FIESC).

Table 3. Understanding of interviewees compared to reference on offset.

\begin{tabular}{|c|c|}
\hline AUTHORS & DEFINITIONS \\
\hline $\begin{array}{l}\text { Author } 1 \text { - Ministry of Defense of Brazil } \\
\text { (Brasil, 2002) }\end{array}$ & $\begin{array}{l}\text { "Any compensatory practice agreed between } \\
\text { the parties, as a condition for importing } \\
\text { goods, services and technology, with the } \\
\text { intention of generating industrial, } \\
\text { technological and commercial benefits. " }\end{array}$ \\
\hline $\begin{array}{l}\text { Author } 2 \text { - Office of Management and Budget } \\
\qquad(\text { OMB, 1988, p.82) }\end{array}$ & $\begin{array}{l}\text { "A range of industrial and commercial } \\
\text { compensation practices required as a } \\
\text { condition for the purchase of military } \\
\text { exports." }\end{array}$ \\
\hline Interviewee from Wega & $\begin{array}{l}\text { "All offset is a return of their investment in } \\
\text { Brazilian companies to produce certain } \\
\text { goods." }\end{array}$ \\
\hline Interviewee from, FIESC & $\begin{array}{l}\text { "It is participation, either in capital or in } \\
\text { technology." }\end{array}$ \\
\hline
\end{tabular}

By authors (2017).

Among the perceptions raised by the study with the managers and employees regarding the offset tool, it was possible to identify a discussion about the legal framework of commercial offset in Brazil. The analysis and the counting of words indicated the occurrence of several terms related to the subject "legislation". The concern was expressed repeatedly among the interviewees.

In view of this, it can be inferred that although the interviewees are aware of the legislation regulating the offset in the Brazilian armed forces, they have no idea how the company could benefit from the practice. The market exposes its perception of the law in an ironic way, as we can see in the statements of a Wega Aircraft interviewee, who expresses his feelings regarding the reading of that legal framework by saying that 
"the guy who wrote about the offset, did not know what he was saying and started saying a lot of stuff."

In 2016, another concern was raised regarding the applicability of companies in the aeronautical sector in Santa Catarina to the receipt of offset, since it was raised during the interview that these still need to be homologated by ANAC. According to the statements of one of the interviewees of the company, the process is expensive and bureaucratic, stating that "Approval is a matter of money and document."

Regarding this statement, the interview conducted in 2018 showed that the company advanced on this issue, having received a visit from the Institute of Industrial Development (IFI) responsible in the Air Force for the implementation of offsets agreements and was approved by EMBRAER as a supplier of carbon jigs for EMB-190 family jets.

Also regarding homologation, the content analysis of the interviews held in 2016 indicates that terms derived from the verb "to certify" appeared 14 times throughout the transcriptions, being therefore a central concern, especially by manager, but also by the employees and the director. ${ }^{3}$ In this sense, the director demonstrates his fear about whether these circumstances could possibly be an obstacle in obtaining the offset by the state companies questioning if: "In case of a debate on that, will only the certified companies have access to it?".

Another fragment recovered from that interviewee's speech is the statement that the certification is "a different stage". This points to an indication that there is a tendency in the aeronautical industry in Santa Catarina in regards to offsetting about the need of regulation, clarifying which companies could be beneficiaries, however, without pointing out that certification is a sine qua non condition for that, giving privileges to the first established companies and the experimental aviation pole.

In fact, the interviewees' statements about the certification of companies could be confirmed by the researchers on the ANAC website (2016), observing that the number of companies authorized for the aeronautical construction field that were certified by the organization was very low.

In the new round of interviews in 2018 the company submitted that it received with the support of the Federal University of Santa Catarina the $5 \mathrm{~S}$ certification, but reported that it did not intend to obtain new certifications at that moment, because it had no need, with the exception perhaps of the certifications "ISO ".

In regards to the offsets, the interviews held in 2016 showed that there is also the fear that the process may be corrupted. The owner of the company Wega Aircraft states conclusively that he does not believe "that a decent legislation will emerge (emphasis); that's the word, a decent legislation; to regulate this. And if that happens it will be corrupted. That is my opinion. Aimed at people and entities that are making an effort to receive this business".

These statements follow other ones made throughout the interview and identified in the analysis of the interviewees' positions that corroborate with this reasoning.

Among the reasons that could be pointed out for the skepticism of the sources regarding the transparency of Brazil's commercial offsets policy, previous

\footnotetext{
${ }^{3}$ Prior to the beginning of the research, there was no concern on the part of the researchers about this issue, since there was no idea that companies from Santa Catarina could be operating without ANAC approval, nor that companies could choose to operate under such circumstances. It is important to note that the Committee and the companies are working towards obtaining all the necessary certifications, but they have run into high costs and bureaucracy.
} 
experiences are indicated, such as: - failure to participate in fairs in the sector due to lack of required documents, without given a reasonable time frame for them to be provided; - bureaucratic obstacles faced in the day-to-day of the company to have access to other governmental incentive mechanisms already in use, such as Drawback; - and a distrust of institutions that can be perceived in between the lines of the conversation.

However, these positions did not appear again in the interview in 2018 , and a possible explanation for this situation may be the visit of the IFI to the company, as well as the course of this own research that made possible the increase of the information available to the manager on the subject.

Another concern is the need to transform offset in business. Managers say they do not have time to waste and they point out that although they know the importance of access to the mechanism, they do not have an exact idea of how to turn it into a business, which is expressed by the committee's director with the following statement: "Well, on offset, I get it, he already understands that what we have to know now is how to turn it into business."

The triangulation of the results of the interviews with those of the observation and of the internet sites analyzed, in the case of the analyzes on aspects of the commercial offset tool, did not show any inconsistency of what was said by the interviewees in comparison to the assumptions of the theory.

In general, the interviews conducted in 2016 showed that the interviewees' perception of the offset could be expressed in one sentence: approval of the mechanism and skepticism regarding its applicability. These statements are best illustrated in the words of an informant at Wega Aircraft, who states: "My final opinion of this is that it would be very interesting; would be. Only I do not believe this will happen! "

In the new interview, when asked about the company's ability to absorb offset agreements, the owner said that at that time the company has the technical ability to absorb offsets, and the biggest obstacle to the company at that time would be the financial issue. Regarding a possible increase in demand due to an offset agreement, the company pointed out that in the short term it would not be able to absorb the demands, but that in the medium term it would be able to absorb them.

Such statements are consistent with the same problems pointed out in the interview of 2016, since at that moment the company pointed out that it was searched by a Latin American Air Force, whose name was kept confidential, for the provision of a fleet of aircraft for training of pilots, but who can not accept the request for not being able to meet the demand within the requested deadlines.

With regard to technology transfer, the interviewees show skepticism. Both claim not to believe that it can actually occur. Such perceptions can be expressed in the statements of the director in two moments, in which he says: "Well, in fact, it does not exist. Because technology takes either a lot of money, or a very great understanding between the parties. Technology is the secret; I'm not going to teach you the secret." Right after, he makes a categorical statement: "The secret no one gives away!" The following Table 4 presents the understanding of the director of FIESC and the owner of the company under analysis on the matter of technology transfer. 
Table 4. Understanding of interviewees compared to referential on technology transfer.

\begin{tabular}{cl}
\hline \multicolumn{1}{c}{ AUTHORS } & \multicolumn{1}{c}{ DEFINITIONS } \\
\hline Peters $(2000, \mathrm{~s} / \mathrm{p})$. & $\begin{array}{l}\text { "This is the process by which an existing } \\
\text { technology is applied to a new use or to a } \\
\text { new user." } \\
\text { "Technology transfer is the process by which } \\
\text { a set of knowledge, skills and procedures } \\
\text { applicable to the problems of production are } \\
\text { transferred, by economic transaction, from } \\
\text { one organization to another, enhancing the } \\
\text { innovation capacity of the receiving } \\
\text { organization." }\end{array}$ \\
& $\begin{array}{l}\text { "Well, in fact, it does not exist. Because } \\
\text { technology takes either a lot of money, or a } \\
\text { very great understanding between the } \\
\text { parties. Technology is the secret; I'm not } \\
\text { going to teach you the secret." Right after, } \\
\text { he makes a categorical statement: "The } \\
\text { secret no one gives away!" }\end{array}$ \\
\hline Director at FIESC & "The technology is not transferred."
\end{tabular}

By authors (2018).

One of the concerns perceived by the study is related to the type of technologies that would be transferred, as well as its use for the company. As exemplified in their statements, the director, using a hypothetical case of technology transfer involving aircraft landing gear, said: "The technology, they transfer a part of it, only for the landing gear, for example, to be produced here. But for the aircraft, they do not transfer. I do not believe they would. But here comes the question: isn't this technology obsolete? Of those parts of the aircraft that we will produce here?" The owner of the company Wega Aircraft is also incisive at this point stating that "technology is not transferred."

In order to conclude the analysis of the conversation regarding the perceptions about technology transfer, it can be inferred that the respondents seem to believe, also, that the possibility of this transfer is feasible. It would have the risk of encountering capabilities already installed in the receiving companies, which could even, as expressed in the director's point of view, be made from deals such as the supply of parts of equipment purchased, whose technology already existed in the company under study.

The interviewee also expresses some fear regarding the protection of the technologies of the receiving companies in the middle of the offset reception process. This perception is made clear in the literal transcription of the following statement: "I will answer you in the committee's view, if in the offset there is money coming, and technology coming, represented by a certain value in the Project, it will have as barriers our capabilities we already have, maybe they did not even imagine we had, such as carbon fiber, in which we are experts. Maybe in the coming of the offset they can take advantage of the local expertise to return or to provide to that industry that is coming? Supplying here, who is making parts and pieces, which are small parts of carbon fiber. Ah! But the company is not certified; We will not enter into this matter here. If this offset comes, as a counterpart it cannot take, as it's a second offset, it intended to bring, but in a little while it could also take something, for the equipment that will stay in Brazil."

In the case of the technology, the observation technique indicated that the company relied on many essential parts and components from other companies, such as aircraft 
engines, which it used an engine purchased from another company, as well as parts of avionics. Likewise, the site and other pages visited in the research pointed to similar results.

Therefore, it can be inferred that the existing technology (powertrain and avionics of aircraft) is applied to a new use (new airplane, since the powertrain and avionics were not designed specifically for the airplane developed by the company) and a new user, the company Wega Aircraft, which would configure in the definition of Peters (2000) a type of technology transfer.

\section{Final Considerations}

The present study addressed the role of offset and technology transfer in the attempt to install an aeronautical pole in Santa Catarina / Brazil in a case study of the company Wega Aircraft in the city of Palhoça. The research indicated the non-use of the offset tool by the company researched and the use, although unaware, of technology transfer.

The study served to raise perceptions in the company about the studied tools, which may be useful to think about the limits and possibilities of the use of these mechanisms in their scope, pointing to possibilities of induction through public policies in cities and poles.

As a suggestion for future researches, it is believed that multiple case studies to confront the understanding of offset and technology transfer in different companies in this sector, or between different sectors, are still needed. Quantitative studies (survey) can be useful to measure the scope of the use of tools analyzed at the Brazilian level. These can broaden the understanding of these tools by a large number of managers and stakeholders involved with companies in strategic sectors, which in turn could benefit from the wider use of offset and technology transfer, in case the indicatives of the theory are verified at national level.

Research is also needed to develop methods for evaluating results in organizations where the phenomena are already consolidated, aiming to create strategies to deal with challenges and difficulties encountered by Brazilian companies that wish to implement the tools. Finally, it is still necessary to find an organization, even at an international level, where phenomena are already consolidated as a strategic management tool to evaluate exclusively its use.

Among the limitations of the research, it should be pointed out that the presented data cannot be generalized, since the study is exploratory. The results are not conclusive and the sample element was small, because the company still presents management characteristics where the CEO is the only one responsible for making decisions. As a result, it was necessary to add an external person, but someone with a great influence in this (stakeholder) to broaden the sample element maintaining the high level, since the information obtained from other employees, despite being generally qualified, was limited.

From a theoretical point of view, the research showed in this specific case the pertinence of the analytical framework presented by De Negri $(2006$, p. 28) in the evaluation of the absorptive capacity of Brazilian industrial companies, since elements of this framework could be effectively used in analysis of the organization studied.

Thus, the results obtained here may not represent the industry under study. Finally, the research problem may involve uninvestigated but relevant variables to understand 
reality, which makes continuity of studies an opportunity for greater understanding of these phenomena.

\section{References}

Agência Nacional de Aviação - ANAC. (2019). Empresas Brasileiras certificadas para fabricação de produtos aeronáuticos. Retrieved in 2016, September 5, from http://www2.anac.gov.br/certificacao/Organizacao/EmprHomolog.asp.

Banco Nacional Desenvolvimento Econômico Social - BNDES. (2012). Porte das empresas. Retrieved in 2017, March 15, from http://www.bndes.gov.br/SiteBNDES/bndes/bndes_pt/Navegacao_Suplementar/Perfil/porte .html

Bardin, L. (2009). Análise de conteúdo. São Paulo, SP: Edition 70.

Bell, J. (2008). Projeto de pesquisa: guia para pesquisadores iniciantes em educação, saúde e ciências sociais (4. ed.). Porto Alegre: Artmed.

Bernardes, R. (2000). O caso Embraer-privatização e transformação da gestão empresarial: dos imperativos tecnológicos à focalização no mercado Cadernos de Gestão Tecnológica, 46). São Paulo: CYTED: PGT/USP.

Brasil. Ministério da Defesa. (2008). Decreto $n^{\circ}$ 6.703, de 18 de dezembro de 2008. Aprova a Estratégia Nacional de Defesa e dá outras providências. Brasília, DF: Diário Oficial da República Federativa do Brasil. Retrieved in 2016, May 22, from: http://www.fab.mil.br/portal/defesa/estrategia_defesa_nacional_portugues.pdf

Brasil. Ministério da Defesa. (2002). Portaria normativa $n^{\circ}$ 764, de 27 de dezembro de 2002. Aprova a política e as diretrizes de compensação comercial, industrial e tecnológica do Ministério da Defesa. Brasília, DF: Diário Oficial da República Federativa do Brasil. Retrieved in 2016, January 28, from https://www.jusbrasil.com.br/diarios/830358/pg-19secao-1-diario-oficial-da-uniao-dou-de-31-12-2002

Perlo-Freeman, S. (2004). Offsets and the development of the Brazilian arms industry. In: J. Brauer \& P. Dunne. Arms trade and economic development: theory, policy, and cases in arms trade offsets (pp. 187-204). New York: Routledge. http://dx.doi.org/10.4324/9780203392300_chapter_13.

Cândido, A. C. (2010). Crescimento económico e inovação: Uma reconsideração do modelo de Fagerberg (Dissertação de mestrado). Curso de Economia e Gestão da Inovação, Departamento de Faculdade de Economia da Universidade do Porto, Universidade do Porto, Porto.

Carneiro, W. P. (2008). De frente para o crime: a política externa brasileira diante dos crimes contra a humanidade no pós-guerra fria: da intervenção humanitária à ampliação do Conselho de Segurança. Universitas: Relações Internacionais, 6(2), 39-69.

Cohen, W. M., \& Levinthal, D. A. (1999). Absorptive capacity: A new perspective on learning and innovation. In: R. L. Cross, Jr. \& S. B. Israelit. Strategic Learning in a Knowledge economy (pp. 39-67).

COMDEFESA. (2015). Offset: conceitos, entraves e possibilidades. Retrieved in 2015 , September 01, from: http://www.defesanet.com.br/defesa/noticia/6865/ANALISECOMDEFESA---OFFSET--Conceito--Entraves-e-Possibilidades/

Cornwall, J. (1976). Diffusion, Convergence and kaldor's Law. Economic Journal, 86(342, Suppl. 85), 307-314. http://dx.doi.org/10.2307/2230749.

Cornwall, J. (1977). Modern capitalism: Its growt hand transformation (226 p.). London: Martin Robertson.

Creswell, J. W. (2007). Projeto de pesquisa: Métodos qualitativo, quantitativo e misto (2a ed.). Porto Alegre: Artmed. 
De Negri, F. (2006). Determinantes da capacidade de absorção das firmas brasileiras: qual a influência do perfil da mão-de-obra. Tecnologia, exportação e emprego. Brasília: Ipea.

Dosi, G. (1984). Technical change and industrial transformation. New York: St. Martin's Press. http://dx.doi.org/10.1007/978-1-349-17521-5.

Dumas, L. J. (2004). Do offsets mitigate or magnify the military burden? In: J. Brauer \& P. Dunne. Arms trade and economic development: Theory, policy, and cases in arms trade offsets (pp. 16-29). New York: Routledge. http://dx.doi.org/10.4324/9780203392300_chapter_1.

Fagerberg, J. (1987). A technology gap approach to why growth rates differ. Research Policy, 16(2-4, Suppl. 16), 87-89. http://dx.doi.org/10.1016/0048-7333(87)90025-4.

Fernandez, F. (2015). Transferência de tecnologia e parcerias estratégicas: Limites e Possibilidades do offset para a Indústria Aeronáutica Catarinense (Dissertação de mestrado). Curso de Administração, Unisul, Florianópolis.

Fernandez, F., Almeida, P., \& Ricardo, S. Acordo entre o Governo da República Federativa do Brasil e o Governo da República Francesa na área de submarinos: um estudo de caso de acordo internacional de transferência de tecnologia no setor militar sob a óptica brasileira. In: Anais do I Seminário Brasileiro de Estudos Estratégicos Internacionais - SEBREEI (p. 125-142). 2012, Porto Alegre: UFRGS.

Fiegenbaum, J., \& Rondinel, R. (2006). Acuerdos offset de compensación comercial, industrial y tecnológica-Un estudio del caso brasileño. Observatorio de la Economía Latinoamericana, n. 68.

Flick, U. (2009). Introdução à pesquisa qualitativa. Porto Alegre, RS: Artmed.

Flores, J., Jr. (1998). O Primeiro Jato! O Gloster Meteor F-8/TF-7 na FAB. Revista Força Aérea, 1(10), 92-112.

Franco, M. L. (2008). Análise do conteúdo. Brasília: Líber Livro Editora.

G1 (2013, Março 29). Aviões experimentais construídos em SC voam até os EUA para feira: Viagem até Flórida serão de 8 mil quilômetros e terá oito escalas: Empresários comparam desempenho de nave a carro da marca Ferrari. G1 Santa Catarina. Retrieved in 2016, March 29, from http://g1.globo.com/sc/santa-catarina/noticia/2013/03/avioesexperimentais-construidos-em-sc-voam-ate-os-eua-para-feira.html

Godinho, M. M. (1995). Difusão internacional de tecnologia e perspectivas de convergência: onde se encontra a economia portuguesa? Sociologia: Problemas e Práticas, 18, 9-21.

Instituto Nacional da Propriedade Industrial - INPI. (2005). Nacional da Propriedade IndustrialApresentação Março de 2005. Retrieved in 2011, March 25, from: http://www6.inpi.gov.br/

Ivo, R. C. (2004). A Prática do Off-Set como instrumento dinamizador do desenvolvimento industrial e tecnológico (Dissertação de mestrado). Universidade Nacional de Brasília, Brasília. $157 \mathrm{p}$.

Jones, C. I. (2000). Introdução à teoria do crescimento económico (1a ed.). Rio de Janeiro: Campus. $192 \mathrm{p}$.

Kupfer, D. (1996). Uma abordagem neo-schumpeteriana da competitividade industrial. Ensaios FEE, 17(1), 355-372.

Liesch, P. W., \& Palia, A. P. (1999). Australian perceptions and experiences of international countertrade with some international comparisons. European Journal of Marketing, 33(5/6), 488-512. http://dx.doi.org/10.1108/03090569910262062.

Lindbeck, A. (1983). The recent slow down of productivity growth. Economic Journal, 93(369, Suppl. 93), 13-34. http://dx.doi.org/10.2307/2232162.

Modesti, A. (2004). Offset: teoria e prática. In Z. Warwar (Ed.), Panorama da Prática de Offset no Brasil: uma visão da negociação internacional de acordos de compensação comercial, industrial e tecnológica. Brasília, DF: Projeto Editorial/Livraria Suspensa. 
Nelson, R. R., \& Winter, S. G. (1982). An evolutionary theory of economic change. Cambridge: Harvard University Press.

Office of Management and Budget - OMB (1988). Exevutive office of the president. Report on offsets in military exports. Washington, DC. $135 \mathrm{p}$.

Palia, A. P. (1992). Countertrade practices in Indonesia. Industrial Marketing Management, 21(3), 273-279. http://dx.doi.org/10.1016/0019-8501(92)90025-O.

Palia, A. P. (1993). Countertrade practices in Japan. Industrial Marketing Management, 22(2), 125-132. http://dx.doi.org/10.1016/0019-8501(93)90038-9.

Palia, A. P., \& Liesch, P. W. (1991). Recent trends in Australian countertrade: A cross-national analysis. Asia Pacific Journal of Management, 8(1), 85-103. http://dx.doi.org/10.1007/BF01731919.

Palia, A. P., \& Liesch, P. W. (1997). Survey of countertrade practices in Australia. Industrial Marketing Management, 26(4), 301-313. http://dx.doi.org/10.1016/S0019-8501(96)00118-6.

Palia, A. P., \& Yoon, H. D. (1994). Countertrade practices in Korea. Industrial Marketing Management, 23(3), 205-213. http://dx.doi.org/10.1016/0019-8501(94)90034-5.

Parvin, M. (1975). Technological adaptation, optimum level of back wardnes sand the rate of per capita income growth: an econometric approach. The American Economist, 19(1, Suppl. 19), 23-31. http://dx.doi.org/10.1177/056943457501900104.

Peters, D. M. (2000). Technology transfer - Editorial. Welding Design e Fabrication, Novembro/2000.

Petersen, C. D. (2011). Defense and commercial offsets: impacts in the U.S. industrial base rase economic and national security concerns. Journal of Economic Issues, 42(2), 485491.

Rocha, I. (1996). Ciência tecnologia e inovação: conceitos básicos. Brasília: SEBRAE. 131 p.

Rogers, E. M. (2010). Diffusion of innovations. New York: Simon and Schuster.

Vargas, M. V. (2004). Una Mirada económica la los acuerdos de offsets en el Sector Defensa y Seguridad en Colombia. Colombia: República de Colombia, Departamento Nacional de Planeación Dirección de Estudios Económicos.

Viotti, E.B., Guimarães, A. O., Hollanda, S., Galvão, A. C. F., \& Parês, A. C. G. (1997). Dimensão Econômica da Inovação (Coleção Curso de Especialização em Agentes de Difusão Tecnológica). Brasília: ABIPTI/SEBRAE/CNPq. 26 p.

WEGA. (2016). WegaAircraft. Retrieved in 2016, April 15, from: http://www.aerowega.com/ Welt, L. G. B. (1986). Offset as a competitive tool. Global Perspective, 1/janeiro, 485-491.

Yin, K. (2009). Case study research: design and methods. California: Sage Publications. 